\title{
Functional and Regulatory Analysis of the Two Copies of the fixNOQP Operon of Rhizobium leguminosarum Strain VF39
}

\author{
Andreas Schlüter, ${ }^{1}$ Thomas Patschkowski, ${ }^{1}$ Jürgen Quandt, ${ }^{2}$ L. Brent Selinger, ${ }^{3}$ Stephan Weidner, ${ }^{1}$ \\ Maria Krämer, ${ }^{1}$ Luming Zhou, ${ }^{3}$ Michael F. Hynes, ${ }^{2}$ and Ursula B. Priefer ${ }^{1}$ \\ ${ }^{1}$ Ökologie des Bodens, Botanisches Institut, RWTH Aachen, Worringerweg 1, D-52056 Aachen, Germany; \\ ${ }^{2}$ Department of Biological Sciences, University of Calgary, Calgary AB, T2N 1N4, Canada; and \\ ${ }^{3}$ Agriculture Canada, Lethbridge Research Station, BOX 2000 Main, Lethbridge AB, T1J 4B1, Canada \\ Received 11 December 1996. Accepted 21 March 1997.
}

DNA corresponding to two copies of the Rhizobium leguminosarum bv. viciae strain VF39 fixNOQP operon coding for a putative symbiotic terminal oxidase of the hemecopper oxidase superfamily was cloned, sequenced, and genetically analyzed. The first copy is located upstream of the fixK-fixL region on plasmid pRleVF39c, whereas the second copy resides on the nodulation plasmid pRleVF39d. Insertional mutagenesis with antibiotic resistance cassettes confirmed that both copies were functional, and that the presence of at least one functional copy was required for nitrogen fixation. The deduced amino acid sequences of both fixN genes are highly similar (95\% identity) and contain 15 putative transmembrane helices, suggesting that the fix $N$ gene products are integral membrane proteins. Furthermore, six histidine residues predicted to be the ligands for a heme-copper binuclear center and a low-spin heme b are conserved in both $R$. leguminosarum fix $N$ proteins. The deduced fix $O$ and fix $P$ gene products show characteristics of membrane-bound monoheme and diheme cytochrome c, respectively. Upstream of both fixN copies putative Fnr-consensus binding sites (anaeroboxes) were found that differ in certain base pairs. As R. leguminosarum VF39 possesses two members of the Fnr/FixK regulator family, FnrN and FixK, the possible differential regulation of both fixN copies was analyzed with fixNgusA reporter gene fusions. Both fixN fusions were induced under free-living microaerobic conditions and in the symbiotic zone of the root nodule. Induction of the expression of fix Nc and fix Nd was highly reduced in a fnrN mutant background and in a fixL mutant background, whereas fixK was only marginally involved in fixN regulation.

Corresponding author: Michael F. Hynes, Department of Biological Sciences, University of Calgary, 2500 University Dr. NW, Calgary, AB, Canada T2N 1N4; Phone: 403-220-8473; FAX: 403-289-9311; E-mail: hynes@acs.ucalgary.ca

Present address of J. Quandt: AgrEvo Canada Inc., 104-108 Research Drive, Saskatoon, Saskatchewan, S7N 3R3 Canada.

Present address of L. Zhou, Department of Human Genetics, University of Utah, Salt Lake City, Utah 84112, U.S.A.

Nucleotide and/or amino acid sequence data are to be found at EMBL as accession numbers Z80340 and Z80339.
Residual expression of fix $N$ was observed in an fnrN/fixK double mutant.

Additional keywords: Fnr-like regulators.

Bacteria that form nitrogen-fixing nodules on the roots of leguminous plants (collectively known as rhizobia) have been intensively studied because of their agronomic importance and the inherent biological interest of their complex interactions with their host plants. Use of molecular genetic tools and techniques has revealed that although the rhizobia are phylogenetically diverse, falling into at least four genera (MartinezRomero and Caballero-Mellado 1996 and references therein), common sets of genes involved in their interactions with plants are quite conserved (for reviews see Fisher and Long 1992; Long and Staskawicz 1993; Fischer 1994; Van Rhijn and Vanderleyden 1995). Nodulation (nod) genes specify the synthesis of soluble factors that induce the plant to nodulate, nif genes code for the components (shared by all diazotrophs) necessary for synthesis of a functional nitrogenase enzyme, and fix genes have been classified as genes essential to the symbiotic, rather than free-living, nitrogen-fixing state. This latter classification is, however, not entirely accurate, as homologues of " $f i x$ " genes have been found recently in both free-living nitrogen fixers and nondiazotrophs (e.g., Tripathi 1993; Schlüter et al. 1995).

An important cluster of fix genes with a variety of functions was first discovered in Rhizobium meliloti (Renalier et al. 1987; David et al. 1987). This cluster of genes includes regulatory genes fixLJ (David et al. 1988) and fixK (Batut et al. 1989), the fixGHIS genes coding for a putative cation pump (Kahn et al. 1989), and the fixN operon (Batut et al. 1989; Kahn et al. 1993), whose function was unclear, but whose regulation was fixLJ and fixK dependent. Subsequent studies in Bradyrhizobium japonicum (Anthamatten et al. 1992; Fischer 1994; Preisig et al. 1993, 1996a), Azorhizobium caulinodans (Kaminski et al. 1991; Mandon et al. 1993, 1994), and Rhizobium leguminosarum (D'hooge et al. 1995; Patschkowski et al. 1996) have revealed that elements of this gene cluster are well conserved in the rhizobia, but that there are important differences in gene organization, regulation, and symbiotic relevance of the fix genes. The actual physiological 
role of the proteins encoded by the fixNOQP and fixGHIS operons has been demonstrated most clearly in B. japonicum. (Preisig et al. 1993, 1996a, 1996b; Zufferey et al. 1996). There is compelling evidence that the fixNOQP operon codes for an electron transport chain terminating at an oxidase with a high affinity for oxygen (Preisig et al. 1996b; Zufferey et al. 1996) and that genes of the fixGHIS operon are necessary for synthesis or assembly of a functional FixNOQP complex (Preisig et al. 1996a).

Rhizobium leguminosarum is the type species of the genus Rhizobium (Jordan 1984) and is divided into biovars based on host-specificity. Biovar viciae nodulates the plants of the genera Pisum, Lens, Lathyrus, and Vicia (peas, lentils, sweet peas, and vetches, respectively), while biovar trifolii nodulates clovers (Trifolium spp.) and biovar phaseoli nodulates common beans (Phaseolus spp.). Nodulation and nitrogen fixation by $R$. leguminosarum have been studied in great detail, but when this work was initiated, little information was available on the organization and regulation of fix genes analogous to the $R$. meliloti fix cluster described above. In particular, since it had been shown that three different plasmids in $R$. leguminosarum bv. viciae were involved in formation of functional nitrogenfixing nodules (Hynes and McGregor 1990), we were interested in determining the location of homologues to the $R$. meliloti fixL, fixJ, fixK, fixNOQP, and fixGHIS genes, and elucidating their role in symbiosis. Here we describe the identification, localization, isolation, and characterization of two copies of the fixNOQP operon in R. leguminosarum bv. viciae. The importance of the two fixN operons for symbiotic nitro-

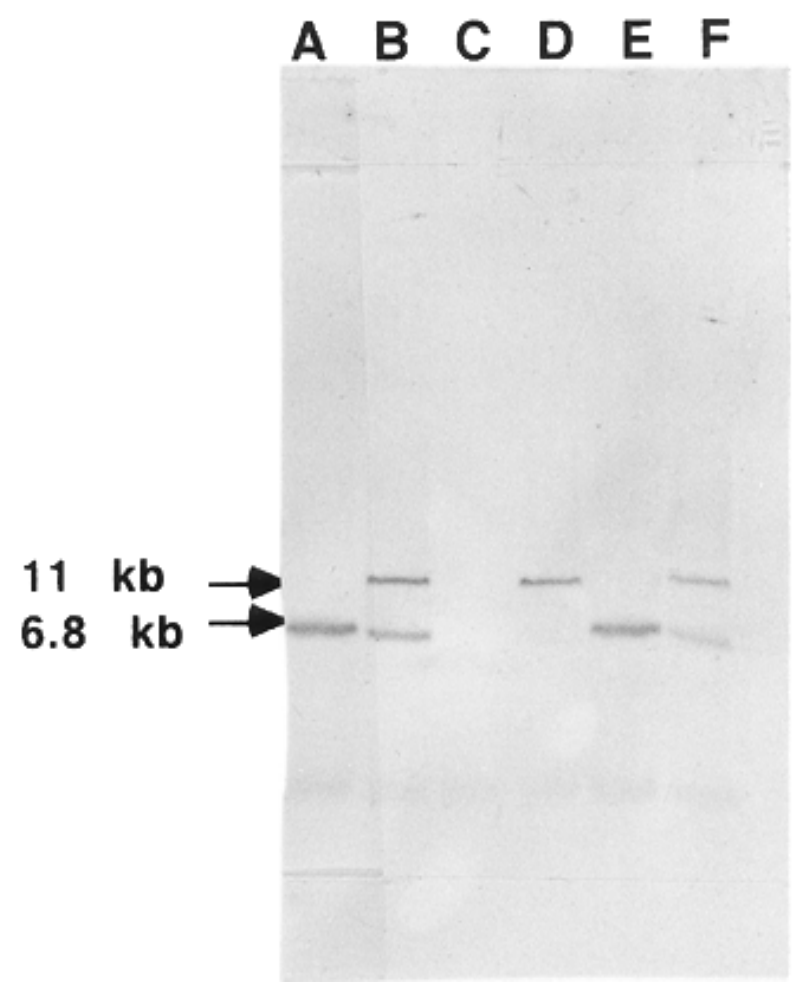

Fig. 1. Hybridization of total DNA digested with EcoRI from Rhizobium leguminosarum derivatives to $R$. meliloti fixN probe from pLZC4. Lane A: LRS39301; lane B: VF39SM; lane C: LRS393401; lane D: LRS39401; lane E: LRS39301; lane F: LRS39501. gen fixation and the influence on expression of both fixN copies of the two Fnr-like regulators FnrN and FixK and the putative oxygen-sensor FixL were analyzed. Preliminary reports of this work have been presented at the 13th North American Conference on Symbiotic Nitrgogen Fixation, Banff, Alberta, Canada, the 6th International Symposium on Molecular Plant Microbe Interactions, Seattle, WA, and the 9th International Congress on Nitrogen Fixation, Cancun, Mexico.

\section{RESULTS}

\section{Identification and cloning of the two fixNOQP copies from R. leguminosarum bv. viciae.}

Since previous studies had shown that two plasmids of $R$. leguminosarum strain VF39, in addition to the nodulation plasmid, were required for formation of a functional nitrogenfixing nodule (Hynes and McGregor 1990), we were interested in exploring the possibility that known fix genes might reside on these plasmids. As, at the time this work was initiated, the location of the genes corresponding to the $R$. meliloti fixL-J-K-NOQP-GHIS cluster had not been firmly established, we set out to use DNA fragments from this cluster as probes. To identify fixN homologous genes in $R$. leguminosarum bv. viciae, a $R$. meliloti fixN probe was hybridized to total DNA of strain VF39. The fixN probe from plasmid pLZC4 (a 1.7-kb PstI fragment carrying the $5^{\prime}$ part of $R$. meliloti fixN) hybridized to an 11-kb EcoRI fragment and a $6.8-\mathrm{kb}$ EcoRI fragment. The $6.8-\mathrm{kb}$ fragment was absent in strain LRS39401 cured of pRleVF39d (the nodulation plasmid) whereas the 11$\mathrm{kb}$ fragment was no longer present in strain LRS39301 cured of pRleVF39c. Strain LRS393401, missing both plasmids pRleVF39c and pRleVF39d, showed no homology to the fixN probe (Fig. 1). Therefore, it could be concluded that $R$. leguminosarum bv. viciae contains two copies of a fixN homologous region present on plasmids pRleVF39c and pRleVF39d. The 6.8-kb EcoRI fragment carrying one copy of the R. leguminosarum fixN homologous region was cloned from a partial library of VF39 DNA generated by cloning DNA from plasmids pRleVF39c and pRleVF39d purified from Eckhardt gels (see Material and Methods). One recombinant clone (pLZC6) carrying the 6.8-kb EcoRI was identified by hybridization to the $R$. meliloti fixN probe. Plasmid pLZC6 (fixN homologous region of plasmid pRleVF39d) was used as a probe for colony hybridization experiments to screen a cosmid library of VF39 total DNA in order to isolate the second fixN homologous region. Two overlapping cosmid clones (pLBS3 and pLBS4) were isolated that contained DNA that originated from pRleVF39c and hybridized to pLZC6 and the R. meliloti fixN probe. An 11-kb EcoRI fragment hybridizing to the fixN probe was subcloned from cosmid pLBS3 into pBluescript-IIKS, resulting in plasmid pFG92. As well, two overlapping cosmids carrying the pRleVF39d fixN copy (pLBS1 and pLBS2) were isolated. Further hybridizations to these cosmids revealed that all contained, immediately adjacent to the fixN homologous region, DNA homologous to probes based on the $R$. meliloti fixGHIS operon. The characterization of these reiterated fixGHIS genes will be presented elsewhere (M. J. Mitsch, P. Rochepeau, J. Quandt, and M. F. Hynes, unpublished). fixL homologous regions were also detected upstream from the fixN operon on pRleVF39c, but not pRleVF39d (see 
also Patschkowski et al. 1996), although use of probes from $R$. meliloti corresponding to this gene had not revealed any homology at the total DNA level. A genetic map of the regions of pRleVF39c and pRleVF39d carrying the fix genes, based on restriction analysis, hybridization, and DNA sequencing (see below), is shown in Figure 2.

\section{Sequence analysis of the two $R$. leguminosarum bv. viciae fixN homologous regions.}

To localize the fixN homologous region on the 11-kb EcoRI fragment originating from pRleVF39c and present on plasmid pFG92, hybridization experiments to subclones with the $R$. meliloti fixN probe were performed. In this way, the fixN homologous region could be delimited to a 2.6-kb HindIII/ BamHI subfragment of plasmid pFG92. The complete nucleotide sequence of this fragment was established on both strands (part of this sequence has been published previously by Patschkowski et al. 1996). In addition, a 3-kb XhoI fragment overlapping the 2.6-kb HindIII/BamHI fragment by $147 \mathrm{bp}$ was used for sequencing of the complete fixNOQP operon. The sequence of $1,651 \mathrm{bp}$ of this XhoI fragment was determined on both strands. An open reading frame (ORF) of 1,617 bp coding for a protein of 539 amino acids (aa) with a calculated molecular weight of 60.9 was identified (see Figure 3); the deduced protein sequence is homologous to FixN and CcoN proteins of different species (94.8 to 63\% identity; see Table 1). A putative ribosomal binding site is located $7 \mathrm{bp}$ upstream of the fixNc ATG start codon (c denotes that the fixN operon is present on plasmid pRleVF39c), and a DNA sequence motif (TTGAT-N4-ATCAA) that is identical to the Fnr-consensus binding site was found 77 bp upstream of the fixNc start codon. Downstream of fixNc, three other ORFs of $732 \mathrm{bp}$ (244 aa, $27.2 \mathrm{kDa}), 150 \mathrm{bp}(50 \mathrm{aa}, 5.5 \mathrm{kDa})$, and 861 bp (287 aa, $30.8 \mathrm{kDa}$ ) were found, the deduced gene products of which are homologous to rhizobial FixO, FixQ, and FixP proteins and therefore were designated accordingly. All three genes were preceded by convincing ribosomal binding sites 6 to $8 \mathrm{bp}$ upstream of the ATG start codon, respectively. Hybridization analysis revealed that the fixN homologous region present on plasmid pLZC6 ( $f i x N d$ ) could be delimited to a 2$\mathrm{kb}$ XhoI fragment (see Figure 2B). One long ORF of 1,620 bp was detected after sequencing of the 1,997-bp XhoI fragment. The corresponding gene product of 540 aa with a calculated molecular weight of 61 shows $94.8 \%$ similarity to the $R$. leguminosarum VF39 fixNc gene product originating from plasmid pRleVF39c and $81.3 \%$ similarity to FixN of $R$. meliloti. A putative ribosomal binding site is located 7 bp upstream of the ATG start codon and a DNA sequence motif

A
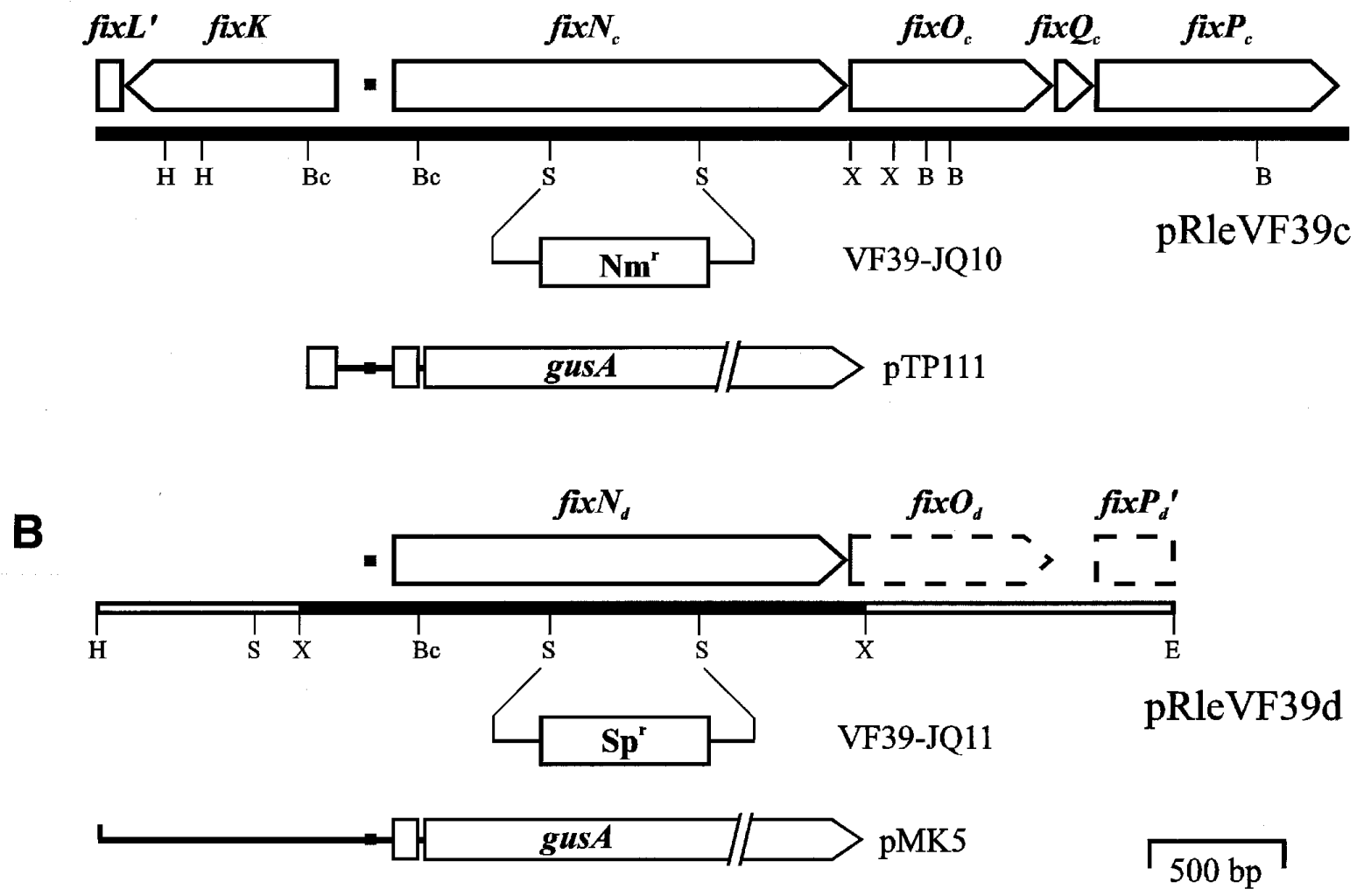

Fig. 2. Physical and genetic maps of the two Rhizobium leguminosarum VF39 fixN regions. One fixN copy is located upstream of the fixK gene on plasmid pRleVF39c (A); the second fixN copy resides on plasmid pRleVF39d (B). Open reading frames (ORFs) homologous to rhizobial fixK, fixL, and fixNOQP are indicated. Black lines indicate DNA regions sequenced on both strands. ORFs homologous to rhizobial fixO and fixP on plasmid pRleVF39d are represented by broken lines because they were deduced from partial DNA sequence analysis. Black squares upstream of both fixN copies represent DNA motifs highly similar to the Fnr-consensus binding site (anaerobox). Insertions of two ( $\mathrm{Nm}^{\mathrm{r}}$, neomycin resistance, and $\mathrm{Sp}^{\mathrm{r}}$, spectinomycin resistance) of the resistance gene cassettes used for mutational analysis are shown below restriction map. Other constructs described in text and in Quandt and Hynes (1993). Plasmids pTP111 and pMK5 carry fixNc-gusA and fixNd-gusA transcriptional reporter gene fusions, respectively. Location of restriction sites: B, BamHI; Bc, BclI; E, EcoRI; H, HindIII; S, SalI; and X, XhoI; given for both fixN regions (only those BclI sites relevant for the construction of gusA reporter gene fusions are shown). 
(TTGAC-N4-ATCAA) that is very similar to the Fnr-consensus binding site was found 77 bp upstream of the fixNd start codon Nine base pairs downstream of fixNd there is the beginning of an incompletely sequenced ORF that shows homology to rhizobial fix $O$ genes. A possible fix $O$ ribosomal binding site overlaps the fixN stop codon by 2 bp. Furthermore, partial DNA sequence analysis revealed the presence of a gene homologous to fixP downstream of fixO. Sequencing of the fixGHISd operon of VF39 also revealed the $3^{\prime}$ end of an intact ORF with high homology to fixP genes (M. J. Mitsch, P. Rochepeau, J. Quandt, and M. F. Hynes, unpublished). The presence of a fix $Q$-like gene downstream of fix $O$ remains speculative since no sequence information is currently available on that region. No genes with similarity to rhizobial fixL, fixJ, or fixK could be detected upstream of fixNd by partial DNA sequence analysis. Comparison of the two R. leguminosarum bv. viciae fixN gene products revealed that they are highly similar to each other (only 28 aa substitutions over a

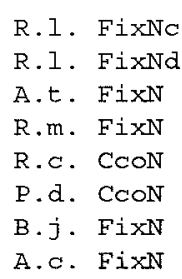

R.1. FixNc R.1. FixNd A.t. FixN R.m. FixN R.C. CCON P.d. CCON B.j. $\mathrm{FixN}$ A.C. FixN

R.1. FixNC R. 1. FixNd A.t. FixN R.m. FixN R.C. CCON p.d. $\mathrm{CCON}$ B.j. FixN A.C. FixN

R.1. FixNc R.1. FixNd A.t. FixN R.m. FixN R.C. CcON P.d. $\operatorname{CcoN}$ B.j. FixN A.C. FixN

R.1. FixNC R.1. FixNd A.t. FixN R.m. FixN R.C. CCON P.d. CCON B.j. FixN A.C. FixN

MNYTTETMVIAVAAFIALLGAAFAH--DHLFAVHMGILCFCLAVGAAL MNYTTETMVIAVAAFLALILIAAFAH- -DHLFAVHMGILCFCLAAGAAV MNYTLETADRALGAFPALLGAAFAH - DSLFAAFMWVIFFTLVVSTLL MKHTVEMVVLSVGAFTALVGAGLAQ- - DRLFGAHMWVLFFALLAGTLV MWDYVKIVALGVVAAIAAYAASQAR - - DLPYMVNMVEVALAAVIALIW MLDTIKLIALGT IAVLAA IAANYAR PDDLAYLVNALI IMLAAGIMFLR MSQPS ISKSMT IGESGLAVVFAATAFLCVIAAAKAL- -DAPFAFHAALSAAASVAAVFC MS IVQTPAKRMTGGELGLILVFAALGFFS IVVAAKAY - T PEYAFHAYLFAAAS IATVFV

$$
\text { III }
$$

LVRNVDFS PQ- PTAESR- -YISYFDEVIRYGLIATVEWGVVGELVGVVIALQLAYPDLNI LIRRVDFS PAGQRRKVD- - ISGYFDEVIRYGLIATVFWGVVGFLVGVVIALQLAFPDLNI LLRRVSFLPPVAGPPCR - -RTEYFDEVVKYGVMATVFWGVVGFLVGVVVALQLAFPDLNI LMRRVDFRPAVAGHPGR - RREYFDEVVKYGVVATVFWGVVGFLVGVVVALQLAFPELNV VLRTMGDPKPSKD- - - - - -EYFDGVIRAGVIATTFWGIVGFLVAVVIAFQLAFPALNL VLRQMGNEQPALEPHPE- - TQYMDDVVRAGVIATAFWGVVGFLVGVVIAFQLAFPALNL IVNRYFERPAAL PPAE INGR PNYNMGPI KFSSFMAMFWGIAGFLVGLI IASQLAWPALNF IGNRYMDRPAELPPQTIDGKPNYNMAPVKVGTLLAVFWGIAGFLIGVI IALQMAYPLFNF

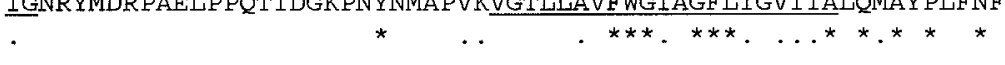

$$
\text { IV }
$$

APY - - - LNFGRLRPVHTSAVIFAFGGNALIMTSFYVVQRTCRARLFGGSLA-WFVFWGY APY - - - LNFGRLRPVHTSAVIFAFGGNAI IMTSFYVVQRTCRARIFGGSLA- WFVFWGY APY - - - FNFGRMRPLHTSAVIFAFGGNALIATSFYVVQRTCRARLFGGNLG-WFVFWGY EPW - - - FNFGRVRPLHTSAVIFAFGGNALIATSFYVVORTSRARLFGGDLG-WFVFWGY EFG-NGMLNFGRLRPLHTSAVIFAFGGNALIASAFYVVQRTSAARLFGGTALGWFVFWGW SDITMGYTNFGKLRPLHTSAVIFAFGGNGLIATSFYVVQRTSAARLWGGNAA-WFVFWGY DLP - - WISFGRLRPLHTSAVIFAFGGNVLIATSFYVVQKSCRVRIAGDLAP-WFVVVGY DLP - - WISFGRLRPLHTSAVIFAFGGNVLIATSFYVVQRTSHARLAGGYLAP-WFVVLGY $* * \ldots * * * * * * * * * * * * * * * * \ldots * * * * * \ldots * * * * \quad \ldots * * \quad *$ VI

QLF I VMAATGYVLGITQAREYAEPEWYVDLWLT I VWVAYLAVYLGTILKRKEPHIYVANW QLF IVMAATGYVLGITQAREYAEPEWYVDLWLT I VWVAYLAVYLGTILKRKEPHIYVANW NLF I IMAATGYLLGITQGREYAEPEWYVDLWLT I VWVAYLATFLGTILTRKEPHISVANW QLFIVLAASGYLLGITQSREYAEPEWYVDLWLT IVWVAYLVAFLGTIMKRKEPHIYVANW QLI IVTAATSYLLGGSQGKEYAELNWHLDILVAVVWVAYLIAFLGTIFKRKEPHIYVANW QLF IVLAATGY ILGATQS KEYAEPEWYVDWWLTVVWVVYLAVFLGTILKRKEPHIYVANW NFFILVAGTGYLLGVTQS KEYAEPEWYADLWLT IVWVVYLLVFLATI I KRKEPHIFVANW NFF I VIAGTGYLLGITQGKEYAEPEWYADLWLT I VWVTYFLVFLGTVLKRKEPHIYVANW

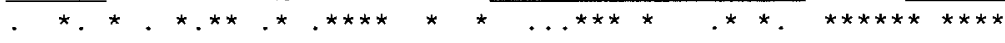
VI I VI I I FYLSFIVTIAMLHVVNNLAVPASFLGSKSYSAFSGVQDALTQWWYGHNAVGFFLTAGFLG FYLAFIVTIAMLHVVNNLAVPVSFLGSKSYSVFSGVQDALTQWWYGHNAVGFFLTAGFLG FYLSFIVTIAMLHI VNNLAVPVSFLGVKSYSAFSGVQAALTQWWYGHNAVGFFLTAGFLG FYLAF IVT IAMLHVVNNLAVPVSFLGSKSYSAFSGVQDALTQWWYGENAVGFFLTAGFLA FYLSFIVT IAMLHI VNNLAVPVS IFGTKSVQLMAGVQDAMTQWWYGHNAVGFFLTAGFLG FYLSFIVT IAMLHI VNNLA I PVSLFGSKSVQLFS GVQDAMTQWWYGHNAVGFFLTAGFLG FYLAFIVTIAVLHLGNNPALPVSAFGSKSYVAWGGIQDAMFQWWYGHNAVGFFLTAGFLA FYLAF ILT IAVLHLGNNAA I PVSVFS PKSY I VWSGVQDAMVQWWYGEMAVGFFLTAGELA

103

104

104

104

98

105 117 118

Fig. 3. Amino acid sequence alignment of the Rhizobium leguminosarum VF39 (R.1.) fixNc and fixNd gene products to the homologous proteins of Agrobacterium tumefaciens (At), (Schlüter et al. 1995), Rhizobium meliloti (Rm), (Kahn et al. 1993), Rhodobacter capsulatus (R.c.), (Thöny-Meyer et al. 1994) Paracoccus denitrificans (P.d.), (de Gier et al. 1996), Bradyrhizobium japonicum (Bj), (Preisig et al. 1993), and A. caulinodans (Ac), (Mandon et al. 1994). Amino acid residues identical in all eight sequences are marked by asterisks. Conservative substitutions are indicated by points. Histidine residues suggested to be involved in heme and copper binding are marked (+). The histidine residue marked by ( $\bullet$ ) has been proposed to be the second axial ligand of the low-spin heme b. Putative transmesmbrane helices are underlined. Continued on next page. 
length of 540 aa; $94.8 \%$ identity). The most striking difference is located in a region from amino acid position 55 to 67 where 9 aa residues are different. All characteristics assigned to the rhizobial fixNOQP gene products are also valid for the corresponding R. leguminosarum proteins: (i) fixNc and fixNd are membrane proteins that contain 15 putative transmembrane helices; (ii) six conserved histidine residues suggested to serve as ligands for the $\mathrm{CuB}$-heme binuclear center and the low-spin heme $\mathrm{b}$ are conserved in both $R$. leguminosarum fixN proteins; (iii) FixOc and FixOd are most probably membrane-anchored cytochrome c proteins that contain a heme c binding motif; (iv) FixQc is similar to rhizobial FixQ proteins (83.6 to $64.5 \%$ identity) and displays a hydrophobic character; and (v) FixPc possesses two heme $\mathrm{c}$ binding motifs (diheme cytochrome $\mathrm{c}$ ) and is predicted to be membrane-anchored since a hydrophobic domain is present near its $\mathrm{N}$ terminus. It exhibits highest homology to R. meliloti FixP, with $67 \%$ identity and $78 \%$ similarity. The DNA sequences for fixNOQPc and fixNd have been deposited into the EMBL database with accession numbers Z80340 and Z80339, respectively.

\section{Phenotype of $R$. leguminosarum bv. viciae strains mutated in fixNc, fixNd, or both.}

To determine the role of the fixN operons for symbiotic nitrogen fixation, single and double mutants were constructed. A fixNd mutant was constructed by replacement of an internal 575-

\begin{abstract}
R.1. FixNC
R.1. FixNd

A.t. FixN

R.m. FixN

R.C. CCON

P.d. CCON

B.j. FixN

A.C. FixN

R.1. FixNc

R.1. FixNd

A.t. $F i x N$

R.m. FixN

R.c. $\mathrm{CCON}$

P.d. CCON

B.j. FixN

A.c. FixN
\end{abstract}

R.1. FixNC

R. 1. FixNd

A.t. FixN

R.m. FixN

R.c. CCON

p.d. $\mathrm{CCON}$

B.j. FixN

A.C. FixN

R.1. FixNC

R.1. FixNd

A.t. FixN

R.m. FixN

R.C. CCON

p.d. CcoN

B.j. FixN

A.C. FixN

R.1. FixNC

R. 1. FixNd

A.t. FixN

R.m. FixN

R.C. CCON

P.d. CCON

B.j. FixN

A.C. FixN

\section{IX}

$++$

MMYYFRPKQANRPVYSYRLS I IHFWAL IFMDI WAGPHHI_HYTALPDWAQTLGMVFS IMLW MMYYFVPKQANR PVYSYRLS I I HFWAL I FMY I WAGPHHLHYTALPDWAQTLGMVFS IMLW MMYYF I PKQVNR PVYSYRLS I I HFWAL I FMY I WAGPHHLHYTALPDWAQTLGMVFS IMLW MMYYFI PKQVNR PVYSYRLS I I HFWA I I FMY I WAGPHHLHYTALPDWAQTLGMVFS IMLW MMYYFVPKQAERPVYSYKLS I VHFWAL IFLY I WAGPHHLHYTALPDWASTLGMVMSVILW MMYYF I PKQAER PVYSYKLS I I HFWAL I FLY I WAGPHHLHYTAI PDWASTLGMVES I ILW IMYYF I PKRAERP I YSYRLS I I HFWAL I FLY I WAGPHHLHYTALPDWTQTLGMTFS IMLW LMYYFI PKRADKPVYS YRLS IVHFWAL I FLY I WAGPEHL HYTAL PDWAQTLGMTFS IMLW

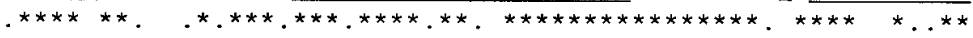
$\mathrm{X}$ $X I$ 395

MPSWGGM INGLMTLSGAWDK IRTDPI IRMMI VA IAFYGMSTFEGPMMSVKTVNSLSHYTE MPSWGGMINGLMTLSGAWDK I RTDP I I RMMI VA I AFYGMSTFEGPMMSVKTVNSLSHYTE MPSWGGMINGLMTLSGAWDK IRTDPIVRMMVMAVAFYGMATFEGPMMS I KAVNSLSHYTD MPSWGGMINGLMTLSGAWDK IRTDPVVRMMVMAVAFYGMATFEGPMMS I KTVNSLSHYTD MPSWGGMINGLMTLSGAWDKLRTDPVIRMMVVS IGFYGMSTFEGPMMS I KAVNSLSHYTD MPSWGGMINGLMTLSGAWDKLRTDP I I RMMVVAVGFYGMATFEGPMMS I KAVNFVSFYTD MPSWGGMINGLMTLSGAWDKLRTDPVLRMLVVSVAFYGMSTFEGPMMS I KVVNSLSHYTD MPSWGGM INGLMTLSGAWDKLRTDP I IRMMVVAVAFYGMATFEGPMMSVKSVNSLSHYTE

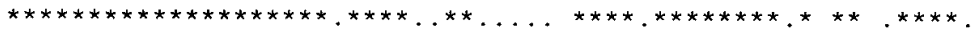
$++\mathrm{XII}$ XIII WTI GHVHSGALGWVGMITFGA IYYLTPKLWGRERLYS PRMVNWHFWLCNLGIVIYAAVLW WT IGHVHSGALGWVGM ITFGA IYYLTPKLWGRERL YSLRMVNWHFWLATLGIVVYAAVLW WT I GHVHSGALGWNGMITFGAIYYLTPKLWGRDRLYSLQLVNWHFWLATLGIVVYAAVMW WT I GHVHS GALGWNGLITFGAIYYLVPKLWNRERLYSVRMVNWHFWLATLGIVVYAAVMW WTI GHVHSGALGWNGMITFGMLYFLTPRLWGR SGLYSLKLVSWHFWLATIGIVLYASAMW WTI GHVHSGALGWNGMITFGALYYLVPRLWGRERLYSTGLVSWHFWLATIGLVLYAASMW WTIGHVHSGALGWVGFVSFGALYCLVPWAWNRKGLYSLKLVNWHFWVATLGIVLYISAMW WGI GHVHSGALGWVAYISFGAIYCLI PWLWNKREMYSMKAIEWHFWVSTLGIVLYICAMW

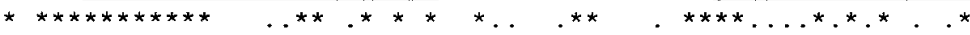
$\mathrm{XV}$

VAGIQQGLMWREYNSQGFLVYSFAETVAAMFPYYVVRAVGGTLYIAGGLVMAWNVFMTIR VAGIOOGLMWREYNS QGFLVYSFAETVAAMF PYYVLRA VGGTLYLAGGLVMAWNVFMTIR VAGIQQALMWREYDSQGFLVYSFAESVAALF PYYVMRALGGLMFLSGALIMAYNVTMTIL VAGIOQGLMWREYDDQGFLVYSFAETVAAMF PYYVMRAAGGALFLAGALLMAFNVTMTIL VTGIMEGLMWREVDAQGFLVNAFADTVAAKF PMYVVRGVGGVLYLLGGLIMAYNLWATVA VSGIMEGLMWREVDAQGFLVNAFADTVAAKF PMNVVRALGGVLYLGGALIMCYNLWATVA VSGI LQGLMWRAYTSLGFLEYS FIETVEAMHPFY I IRAAGGGLFLIGAL IMAYNLWMTVR VAGILQGLMWRAYTALGFLEYSFIETVEAMHPLYVIRA IGGILFLAGSLIMAWNVFMTIT

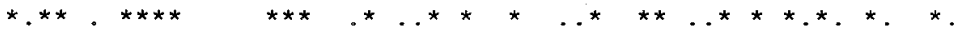

GRLRDEAAI PTTFVPQAQPAE GHLRDEAAI PTTFAPQLQPAE GHQREEGASKG-AAPSLQPAE GRVRDEEPIFG-AAPLPAPAE KQP - KTANLAVAVPAE KQP--KTQSTAAAVPAE VGEAEVQMP - VALQPAE RAETVSQPSGAALAPAE

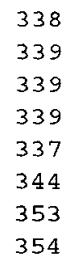

398

399

399

399

397

404

413

414

458

459

459

459

457

464

473

474

518

519

519

519

517

524

533

534

539

540

539

539

532

539

549

551

Fig. 3. Continued from previous page. See previous page for caption. 
Table 1. Comparison of the Rhizobium leguminosarum bv. viciae fixN gene products with related proteins of other species

\begin{tabular}{|c|c|c|c|c|c|c|c|c|}
\hline \multirow[b]{2}{*}{ Protein } & \multicolumn{8}{|c|}{ Amino acid identity (\%) } \\
\hline & R.l. FixNc & R.l. FixNd & A.t. FixN & R.m. FixN & R.c. $C \operatorname{coN}$ & P.d. $C \operatorname{coN}$ & B.j. FixN & A.c. FixN \\
\hline R.l. FixNc & 100 & $\ldots$ & $\ldots$ & $\ldots$ & $\cdots$ & $\cdots$ & $\cdots$ & $\cdots$ \\
\hline R.l. FixNd & 94.8 & 100 & $\ldots$ & $\ldots$ & $\ldots$ & $\ldots$ & $\ldots$ & $\ldots$ \\
\hline A.t. FixN & 81.1 & 82.0 & 100 & $\ldots$ & $\ldots$ & $\ldots$ & $\ldots$ & $\ldots$ \\
\hline R.m. FixN & 80.0 & 81.3 & 85.0 & 100 & $\ldots$ & $\ldots$ & $\ldots$ & $\ldots$ \\
\hline R.c. $\mathrm{CcoN}$ & 65.9 & 67.4 & 66.5 & 66.4 & 100 & $\ldots$ & $\ldots$ & $\ldots$ \\
\hline P.d. $\mathrm{CcoN}$ & 68.6 & 69.5 & 70.7 & 70.0 & 78.7 & 100 & $\ldots$ & $\ldots$ \\
\hline B.j. FixN & 63.1 & 63.8 & 63.6 & 65.4 & 61.4 & 62.9 & 100 & $\ldots$ \\
\hline A.c. FixN & 63.0 & 64.1 & 63.7 & 64.4 & 59.2 & 61.8 & 75.9 & 100 \\
\hline
\end{tabular}

${ }^{\mathrm{z}}$ Comparison of gene products was performed with the align program of the FASTA package (version 1.6c; Pearson 1990). Abbreviations: R.l. = Rhizobium leguminosarum; A.t. = Agrobacterium tumefaciens; R.m. = Rhizobium meliloti $;$ R.c. $=$ Rhodobacter capsulatus; P.d. $=$ Paracoccus denitrificans; B.j. = Bradyrhizobium japonicum; A.c. = Azorhizobium caulinodans.

Table 2. Symbiotic nitrogen-fixation phenotype of Rhizobium leguminosarum bv. viciae fixNc and fixNd deletion/insertion mutants ${ }^{\mathrm{x}}$

\begin{tabular}{|c|c|c|c|c|}
\hline $\begin{array}{l}R \text {. leguminosarum } \\
\text { strain }\end{array}$ & $\begin{array}{l}\text { Relevant } \\
\text { genotype }\end{array}$ & A. $r^{y}$ & $\begin{array}{l}\text { Dry weight } \\
\text { (g per } \\
\text { plant) }^{\mathrm{z}}\end{array}$ & $\begin{array}{r}\text { Total N } \\
\text { (mg per } \\
\text { plant) }\end{array}$ \\
\hline VF39SM & Wild type & + & $0.598 \mathrm{a}$ & $0.886 \mathrm{a}$ \\
\hline VF39-JQ12 & 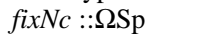 & + & $0.322 \mathrm{ab}$ & $0.384 \mathrm{bc}$ \\
\hline VF39-JQ302 & $\begin{array}{l}\Delta \text { fixNc-fixG:: } \\
\Omega \mathrm{Nm}\end{array}$ & + & $0.417 \mathrm{ab}$ & $0.486 \mathrm{~b}$ \\
\hline VF39-JQ11 & fixNd :: $\Omega \mathrm{Sp}$ & + & $0.448 a b$ & $0.563 \mathrm{ab}$ \\
\hline VF39-JQ321 & $\begin{array}{l}\text { fixNd:: } \Omega \mathrm{Sp}, \\
\text { fixNc-fixG:: } \Omega \mathrm{Nm}\end{array}$ & - & $0.235 \mathrm{~b}$ & $0.269 \mathrm{c}$ \\
\hline Uninoculated control & & - & $0.255 \mathrm{~b}$ & $0.282 \mathrm{c}$ \\
\hline
\end{tabular}

${ }^{x}$ The host plant Pisum sativum (cv. Trapper) was inoculated with the $R$. leguminosarum fixN mutants.

${ }^{y}$ Acetylene reduction. Analyzed 32 days after inoculation.

${ }^{\mathrm{z}}$ Dry weights and total $\mathrm{N}$ values represent the mean values of six plants. Values followed by the same letter are not significantly different at $P=$ 0.05 (least significant difference). Similar results were observed in three independent experiments.

bp SalI fragment by a $\mathrm{Sp}^{\mathrm{r}}$ interposon cassette (Prentki and Krisch 1984; Fellay et al. 1987). This mutation was transferred into the VF39 genome via a double cross-over event resulting in mutant VF39-JQ11. fixNc mutants were constructed by replacement of a fixNc internal 575-bp SalI fragment by $\mathrm{Nm}^{\mathrm{r}}$ and $\mathrm{Sp}^{\mathrm{r}}$ cassettes, as well as by creating a larger deletion encompassing most of the fixNOQP operon and part of fix $G$ (see Materials and Methods). These mutations were transferred into $R$. leguminosarum VF39SM (wt) resulting in mutant strains VF39JQ10, JQ12, and JQ302, and into strain VF39-JQ11, resulting in the fixN/fixNd double mutants VF39-JQ1011 and VF39-JQ321. Nodules induced by the fixNc mutants on Pisum sativum plants showed a Fix ${ }^{+}$phenotype, although shoot dry weight and total nitrogen content of the plants inoculated with this mutant were less than those of plants inoculated with the parent strain, VF39SM (Table 2). The fixNd mutant (VF39-JQ11) showed a similar phenotype. Nodules induced by the fixNc/fixNd double mutants (VF39-JQ321 and VF39-JQ1011) showed a distinct Fix $^{-}$phenotype, demonstrating that both VF39 fixN copies are functional and that at least one functional copy is essential for nitrogen fixation. Plant tests with Vicia hirsuta as a host gave results for mutants similar to those for tests done on $P$. sativum although the statistical significance was less pronounced due to smaller sample and plant sizes.

\section{Analysis of fixNc and fixNd expression under free-living microaerobic conditions}

The presence of putative Fnr-consensus binding sites up-
Table 3. Expression of Rhizobium leguminosarum VF39 fixNc-gusA and fixNd-gusA reporter gene fusions in different mutant backgrounds

\begin{tabular}{llrr}
\hline & & \multicolumn{2}{c}{$\begin{array}{c}\beta \text {-glucuronidase } \\
\text { activity }\end{array}$} \\
\cline { 3 - 4 } $\begin{array}{l}\text { R. legumits) } \\
\text { bv. viciae strain }\end{array}$ & Relevant genotype & Aerobic & $\begin{array}{r}\text { Micro- } \\
\text { aerobic }\end{array}$ \\
\hline VF39SM & Wild type & 21.4 & 18.3 \\
VF39 (pTP111) & Wild type, fixNc-gusA & 19.3 & 159.0 \\
VF39-TP4 (pTP111) & fixL, fixNc-gusA & 14.8 & 44.6 \\
VF39-TP6 (pTP111) & fnrN, fixNc-gusA & 16.5 & 34.5 \\
VF39-TP11 (pTP111) & fixK, fixNc-gusA & 27.2 & 243.0 \\
VF39-TP12 (pTP111) & fnrNIfixK, fixNc-gusA & 20.5 & 38.1 \\
VF39 (pMK5) & Wild type, fixNd-gusA & 19.1 & 115.7 \\
VF39-TP4 (pMK5) & fixL, fixNd-gusA & 17.7 & 45.9 \\
VF39-TP6 (pMK5) & fnrN, fixNd-gusA & 17.7 & 38.1 \\
VF39-TP11 (pMK5) & fixK, fixNd-gusA & 20.4 & 200.4 \\
VF39-TP12 (pMK5) & fnrNIfixK, fixNd-gusA & 16.3 & 33.2 \\
\hline
\end{tabular}

${ }^{\mathrm{z}} \beta$-glucuronidase units were calculated according to Sambrook et al. (1989) and represent the mean values of at least three independent measurements. Standard deviations were less than $23 \%$ in every case.

stream of both fixN copies, together with the model for fixN regulation in $R$. meliloti (Batut et al. 1989), suggested that transcription of the fixN operons is regulated by an Fnr-like regulatory protein. The Fnr-consensus binding sites located upstream of fixNc and fixNd differ in certain base pairs (fixNc: TTGATGTAGATCAA versus fixNd: TTGACGCAGATCAA) and VF39 possesses two known Fnr-like proteins, FnrN and FixK (Schlüter et al. 1992; Patschkowski et al. 1996), so it was possible that the two copies are differentially regulated. Therefore, the influence of these regulatory components on the expression of the fixN operons was analyzed. In addition, fixN expression was studied in a fixL mutant background since fixL codes for a putative oxygen-sensing regulatory component. To analyze fixN expression, gusA transcriptional reporter gene fusions of both fixN copies were constructed. A $B c l$ I restriction site is conserved $75 \mathrm{bp}$ downstream of the ATG start codon in fixNc and fixNd and was used for insertion of a promoterless gusA cassette. The fixNc-gusA and fixNd-gusA fusions, present on the mobilizable plasmids pTP111 and pMK5, respectively, were transferred to $R$. leguminosarum strains VF39SM (wt), VF39-TP4 (fixL), VF39-TP6 (fnrN), VF39-TP11 (fixK), and VF39-TP12 (fnrN/fixK) and integrated into the fixN regions via homologous recombination. Correct integration of the fusions into the corresponding fixN operons (fixNc or fixNd, respectively) was verified by hybridization analysis with labeled fix $\mathrm{Nc}$ and fixNd probes, respectively.

Both fixN-gusA fusions were induced under microaerobic 

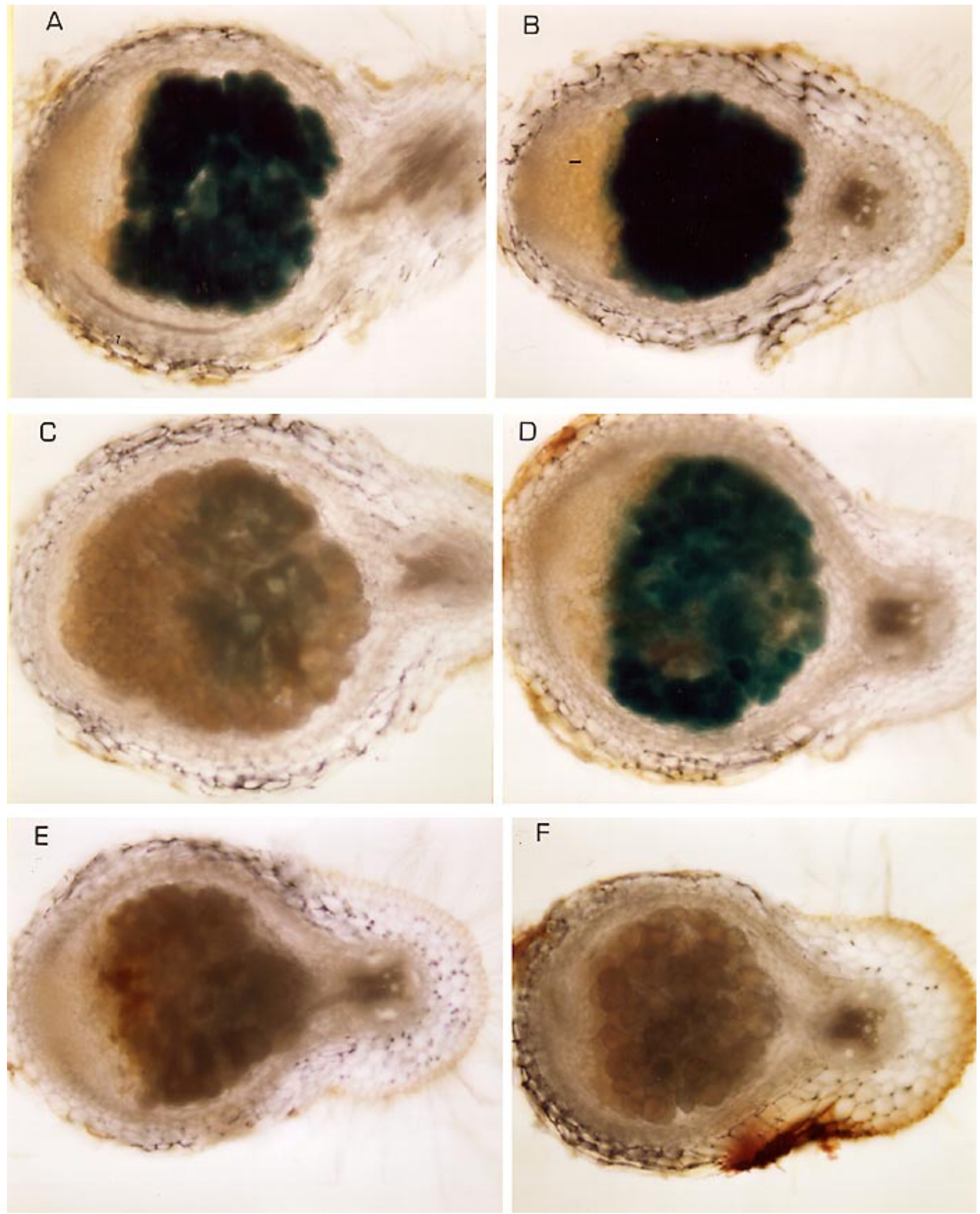

Fig. 4. Symbiotic expression of Rhizobium leguminosarum VF39 fixNc-gusA and fixNd-gusA fusions in Vicia hirsuta root nodules 25 days after inoculation. Sections of root nodules (thickness approx. $100 \mu \mathrm{m}$ ) that were induced by the strains (A) VF39SM (wild type; wt) (pTP111, fixNc-gusA); (B)

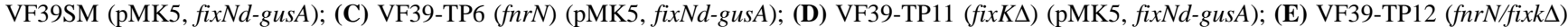
(pMK5, fixNd-gusA); (F) VF39-TP4 (fixL) (pMK5, fixNd-gusA) were stained with X-Gluc (5-bromo-4-chloro-3-indolyl- $\beta$-D-glucuronide) for $\beta$-glucuronidase activity. 
conditions by a factor of 8 for fixNc and 6 for fixNd (Table 3). Induction of fixN expression was impaired in fixL and fnrN mutants (induction factor: 2 to 3 ) whereas fix $N$ expression was even higher in a fixK mutant background, compared with the wild type (induction factor: 9 to 10). A mutation in fixK and fnrN (double mutant VF39-TP12) had nearly the same effect on fixN expression as a single mutation in fnrN (VF39-TP6). Differential responses of fixNc and fixNd to the regulatory components FnrN, FixK, and FixL could not be observed. These results document that FixL and FnrN are involved in positive regulation of both fixN operons under free-living microaerobic conditions, whereas FixK obviously is dispensable for fix $N$ expression.

\section{In situ expression analysis of fixNc-gusA and fixNd-gusA fusions in $V$. hirsuta root nodules.}

To analyze fixN expression in planta, $V$. hirsuta seedlings were inoculated with $R$. leguminosarum strains VF39SM (wild type, wt), VF39-TP4 (fixL), VF39-TP6 ( $f n r N)$, VF39TP11 (fixK), and VF39-TP12 (fnrN/fixK) carrying either the integrated fixNc-gusA or the fixNd-gusA reporter gene fusion. Histochemical analysis of $\beta$-glucuronidase (GUS) expression in the root nodule tissue was done by the GUS-specific staining technique with X-Gluc in longitudinal sections (thickness of about three cell layers) of the nodule. Both fixN-gusA fusions were expressed in the symbiotic zone of the root nodule (Fig. 4). Expression of fixNc and fixNd was highly reduced in fnrN and fixL mutant backgrounds. However, some residual fixN expression could be detected in these mutants. No significant difference could be observed when comparing fixN expression in the fnrN mutant (VF39-TP6) and in the fnrN/fixK double mutant (VF39-TP12). A mutation in fixK had no effect on the expression of either fixN fusion. Differential expression of the fixN copies in response to the regulatory components FixL, FnrN, and FixK could not be observed, and it is for this reason that only the pMK5 derivatives are shown in Figure 4. These results demonstrate that FixL and FnrN are involved in positive symbiotic regulation of fixN expression whereas FixK is dispensable for fixN expression.

\section{DISCUSSION}

The fixNOQP genes and their homologues have now been identified and characterized in four different rhizobia, as well as Agrobacterium, Rhodobacter, and Paracoccus (see references in Figure 3). When the structure of these genes and the flanking sequences in the different rhizobia are analyzed, it can be seen that there are several differences. Both $R$. meliloti (Renalier et al. 1987; David et al. 1988) and R. leguminosarum have two copies of the operon, but in $R$. meliloti they are on the same megaplasmid, whereas in $R$. leguminosarum they occur on different plasmids. This reiteration of fixNOQP on two plasmids is not restricted to strain VF39; we have shown by hybridization that most other strains we have examined have a similar arrangement (data not shown). Bradyrhizobium japonicum and Azorhizobium caulinodans have only one copy of this operon (Preisig et al. 1993; Mandon et al. 1994). All the rhizobia studied so far have fixGHIS genes located downstream from the fixNOQP operon (Kahn et al. 1989; Mandon et al. 1994; Preisig et al. 1996a), although in $R$. meliloti this is true for only one copy of the fixNOQP operon. It is also common for some or all of the fixL, fixJ, and fixK genes to be located upstream of fixNOQP, and this is also true for one copy (the pRleVF39c copy) in VF39 (Patschkowski et al. 1996). However, the orientation of these genes differs in different rhizobia. The arrangement of these fix genes in $R$. etli, the bean symbiont, is remarkably similar to that described in this paper, as there are two copies of fixNOQP on different plasmids, and it is the copy on the plasmid other than the nodulation plasmid that is preceded by fixL (but not fixJ) (Maria de Lourdes Girard, personal communication).

Just as there are differences in arrangement of these genes, there appear to be significant differences in their importance to symbiosis among the different rhizobia, and in the regulation of the genes. Mutants of R. meliloti (Renalier et al. 1987) and $B$. japonicum (Preisig et al. 1993) lacking fixNOQP activity are unable to fix nitrogen symbiotically, whereas $A$. caulinodans mutants retain considerable nitrogen-fixing ability (Mandon et al. 1994). We have shown here that both copies of fixNOQP in VF39 are functional, and that at least one intact copy is required for nitrogen fixation. Single mutants fixed less nitrogen (sometimes significantly so) than wild-type VF39SM in our growth chamber experiments; in fact, if statistical significance was taken at $P=0.1$ instead of $P=0.05$, our results always showed a difference between single mutants and wild type. Therefore, it appears possible that, under field conditions, both copies are required intact for optimal nitrogen fixation.

The data presented here on regulation of both fixN operons under free-living and symbiotic conditions reveal several novel features not seen in other rhizobia studied so far. In $R$. meliloti, FixL, FixJ, and FixK are all required for fixN expression (Batut et al. 1989; David et al. 1988), and this is also the case in both B. japonicum (Preisig et al. 1993) and A. caulinodans (Mandon et al. 1994). In contrast, we have shown here that expression of fixN is largely independent of FixK, and that there is still residual induction of expression of both copies of the fixN operon in the absence of FixL or FnrN. These data are compatible with the fact that although FnrN and FixL do play a role in $\mathrm{N}$ fixation (Colonna-Romano et al. 1990; Patschkowski et al. 1996), they themselves are not absolutely required for $\mathrm{N}$ fixation. The evidence strongly suggests that there is a further regulatory protein that participates in activation of fixN promoters in $R$. leguminosarum, as D'hooge et al. (1995) have also shown that fixL mutants of biovar phaseoli are still able to fix nitrogen. There is evidence from analysis of hup gene expression in strain UPM791 of $R$. leguminosarum bv. viciae that there may be a further copy of an fnrlike gene (Hernando et al. 1995). Alternatively, other, as yet unidentified, proteins may interact with the fixN promoters.

The function of the fixNOQP genes has been most widely studied in $B$. japonicum, where it was first demonstrated that the deduced gene products have characteristics typical of subunits of terminal oxidases. The fix $N$ gene product possesses six conserved histidine residues that serve as ligands for a heme-copper binuclear center and a low-spin heme group. FixO and FixP were predicted to be membrane-anchored cytochrome c proteins (Preisig et al. 1993). Extensive biochemical FixP constitute a cbb3-type oxidase (Preisig et al. 1996b; Zufferey et al. 1996). The fix $Q$ gene product that is also encoded by the fixNOQP operon is dispensable for the function of the cbb3-oxidase. Biochemical analyses of the B. japonicum FixNOP oxidase complex also led to the conclusion that it sup- 
ports microaerobic respiration of bacteroids in the root nodule (Preisig et al. 1996b), and it has now been shown that the genes of the fixGHIS operon are necessary for synthesis or assembly of FixNOQP proteins, and probably encode a copper transport system (Preisig et al. 1996a). It has long been postulated that an alternative terminal oxidase with a high affinity for oxygen is expressed by rhizobia in the bacteroid state (Appleby 1984; Hunt and Layzell 1993), as this would be a prerequisite for energy generation by the rhizobia, most of which are strict aerobes. It now appears quite certain that in all of the rhizobia, the FixN, FixO, and FixP proteins fulfill this function, although A. caulinodans appears to contain a system that can at least partially complement for the absence of FixNOP. Analysis of the results of the present study give further confirmation to this model in that (i) the deduced amino acid sequences of the fixNOQP gene products show all the features of a cbb3-type oxidase system pointed out for $B$. japonicum, (ii) a functional fixNOQP operon is required for nitrogen fixation, and (iii) expression of both copies of the operon is induced under low-oxygen conditions. Very recently, two symbiosis-specific c-type cytochromes and a putative oxidase were identified at the protein level in bacteroids of $R$.

Table 4. Bacterial strains and plasmids

\begin{tabular}{|c|c|c|}
\hline Strains & Relevant characteristics & Source or reference \\
\hline \multicolumn{3}{|l|}{ Escherichia coli } \\
\hline S17-1 & Modified RP4 plasmid integrated into the genome of E. coli 294 recA & Simon et al. (1983) \\
\hline JM83 & $\Delta($ lac pro $)$, thi, $\Phi 80 \mathrm{~d}$, lacZ, $\Delta \mathrm{M} 15$, rpsL & Vieira and Messing (1982) \\
\hline XL1-Blue & $\begin{array}{l}\text { recAl, endA1, gyrA96, hsdR17, supE44, lac, }\left[\mathrm{F}^{\prime} \text { proAB, lacIq lacZ } \Delta \mathrm{M} 15 \text {, }\right. \\
\left.\quad \mathrm{Tn} 10\left(\mathrm{Tc}^{\mathrm{r}}\right)\right], \text { thi }\end{array}$ & Bullock et al. 1987 \\
\hline \multicolumn{3}{|c|}{ Rhizobium leguminosarum bv. viciae } \\
\hline VF39 & Wild type & Hynes et al. (1988) \\
\hline VF39SM & Spontaneous $\mathrm{Sm}^{\mathrm{r}}$ derivative of wild-type VF39 & Priefer (1989) \\
\hline VF39-TP4 & VF39SM fixL::Gm ${ }^{\mathrm{r}}$ mutant & Patschkowski et al. (1996) \\
\hline VF39-TP6 & VF39SM $f n r N:: \mathrm{Gm}^{\mathrm{r}}$ mutant & Patschkowski et al. (1996) \\
\hline VF39-TP11 & VF39SM fixK deletion mutant & Patschkowski et al. (1996) \\
\hline VF39-TP12 & VF39SM fnrN/fixK $\Delta$ double mutant & Patschkowski et al. (1996) \\
\hline LRS39301 & VF39SM, pRleVF39c plasmid cured, Fix ${ }^{-}$ & Hynes and McGregor (1990) \\
\hline LRS39401 & VF39SM, pRleVF39d plasmid cured, Nod $^{-}$ & Hynes and McGregor (1990) \\
\hline LRS393401 & VF39SM, pRleVF39c and d cured, Nod $^{-}$ & This work \\
\hline LRS39501 & VF39SM, pRleVF39e plasmid cured, Fix $^{-}$ & Hynes and McGregor (1990) \\
\hline VF39-JQ10 & 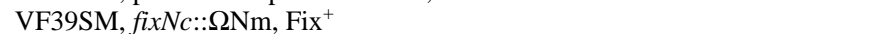 & This work \\
\hline VF39-JQ11 & VF39SM, fixNd::SSp, Fix $^{+}$ & This work \\
\hline VF39-JQ12 & VF39SM, fixNc:: $\Omega \mathrm{Sp}, \mathrm{Fix}^{+}$ & This work \\
\hline VF39-JQ302 & 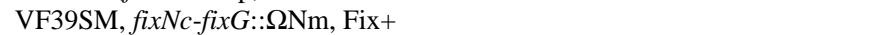 & This work \\
\hline VF39-JQ1011 & 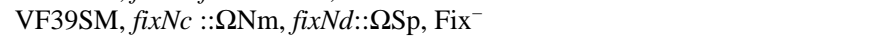 & This work \\
\hline VF39-JQ321 & 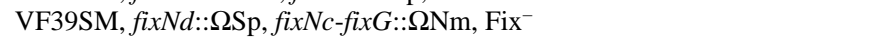 & This work \\
\hline \multicolumn{3}{|l|}{ Plasmids } \\
\hline pBluescript-II & Sequencing vector, $A p^{r}$ & Stratagene (La Jolla, CA) \\
\hline pSVB28 & Sequencing vector, $\mathrm{Ap}^{\mathrm{r}}$ & Arnold and Pühler (1988) \\
\hline pUC18 & sequencing vector, $\mathrm{Ap}^{\mathrm{r}}$ & Yannish-Perron et al. (1985) \\
\hline pSUP202 & pBR325 derivative, mob, $\mathrm{Tc}^{\mathrm{r}}, \mathrm{Ap}^{\mathrm{r}}, \mathrm{Cm}^{\mathrm{r}}$ & Simon et al. (1983) \\
\hline pK18-mob & pK18 derivative, mob, $\mathrm{Km}^{\mathrm{r}}$ & Schäfer et al. (1994) \\
\hline pJQ200KS & pACYC184 derivative, mob $\mathrm{Gm}^{\mathrm{r}}$, $s a c B$, pBluescript-II KS mcs & Quandt and Hynes (1993) \\
\hline pRK7813 & Cosmid vector & Jones and Gutterson (1987) \\
\hline pHP45W & pBR322 derivative $\left(\mathrm{Ap}^{\mathrm{r}}\right)$ carrying a $\mathrm{Sm}^{\mathrm{r}} / \mathrm{Sp}^{\mathrm{r}}$ interposon & Prentki and Krisch (1984) \\
\hline pBI221.1 & pUC19-derivative, gusA cassette & Jefferson (1987) \\
\hline pLZC4 & pBluescript-II $\mathrm{KS}^{+}$derivative, 1.7-kb PstI fragment carrying $R$. meliloti fix $N^{\prime}$ & This work \\
\hline pLZC6 & $\begin{array}{l}\text { pBluescript-II } \mathrm{KS}^{+} \text {derivative, } 6.8-\mathrm{kb} \text { EcoRI fragment carrying the VF39 } \\
\text { fixNd region }\end{array}$ & This work \\
\hline $\mathrm{pLBS} 1 / \mathrm{pLBS} 2$ & pRK7813 cosmid derivatives carrying the VF39 fixNd region & This work \\
\hline pLBS3/pLBS4 & pRK7813 cosmid derivatives carrying the VF39 fixNc region & This work \\
\hline pFG92 & $\begin{array}{l}\text { pBluescript-II } \mathrm{KS}^{+} \text {derivative, } 11-\mathrm{kb} \text { EcoRI fragment carrying the VF39 } \\
\text { fixNc region }\end{array}$ & This work \\
\hline pTP86 & pBluescript-II KS ${ }^{+}$derivative carrying a promoterless gusA cassette & Patschkowski et al. (1996) \\
\hline pTP93 & $\begin{array}{l}\text { pBluescript-II } \mathrm{KS}^{+} \text {derivative, } 3 \text {-kb } X \text { hoI fragment carrying the VF39 } \\
\text { fix } O Q P \text { region }\end{array}$ & This work \\
\hline pTP94 & $\begin{array}{l}\text { pBluescript-II } \mathrm{KS}^{+} \text {derivative, 2.6-kb HindIII/Bam } \mathrm{HI} \text { fragment carrying } \\
\text { VF39 fix } K^{\prime} \text {-fixNO }\end{array}$ & This work \\
\hline pSWS1 & pSVB28 derivative, 2-kb XhoI fragment carrying the VF39 fixNd gene & This work \\
\hline pJQ245 & pJQ200KS derivative, fixNd::SSp & Quandt and Hynes (1993) \\
\hline pJQ302 & pJQ200SK, fixNc-fixG::SNm & Quandt and Hynes (1993) \\
\hline pJQ291 & pJQ200SK, 3.3-kb NotI-XhoI fragment carrying fixL' -fixK-fixNc & This work \\
\hline pJQ292 & 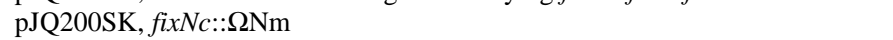 & This work \\
\hline pJQ292Sp & pJQ200SK, fixNc::SSp & This work \\
\hline pTP111 & pSUP202 derivative, fixNc-gusA fusion & This work \\
\hline pMK5 & pK18-mob derivative, fixNd-gusA fusion & This work \\
\hline
\end{tabular}

${ }^{\bar{z}}$ Abbreviations for antibiotic resistances: $\mathrm{Ap}=$ ampicillin; $\mathrm{Cm}=$ chloramphenicol; $\mathrm{Gm}=$ gentamicin; $\mathrm{Km}=$ kanamycin; $\mathrm{Nm}=$ neomycin; $\mathrm{Sp}=\mathrm{spectin}-$ omycin; $\mathrm{Sm}=$ streptomycin; $\mathrm{Tc}=$ tetracycline . 
leguminosarum bv. viciae (Vargas et al. 1996), and it now appears quite likely that these proteins correspond to the products of the genes of the fixNOQP operons.

It is still unclear why $R$. meliloti and $R$. leguminosarum have two copies of the fixNOQP operon, whereas $B$. japonicum and $A$. caulinodans have only one. Our study showed no evidence of differential regulation of the two copies, and this question has not yet been addressed in $R$. meliloti. However, our results from measurements of total nitrogen in plants inoculated with mutants in single copies of fixN do suggest that both copies are required for optimal fixation of nitrogen. Measurements of acetylene reduction did not reveal this difference but this is not surprising, as acetylene reduction measures fixation at only one point in time, and not over the growth cycle of a plant. It is thus important to use other parameters to assess symbiotic performance, as we have done in this study. Since it appears to be the case that a single copy of fixNOQP does not give optimal symbiotic performance, it is interesting to speculate that increased expression of this operon might be a means to enhance nitrogen fixation in genetically engineered strains of $R$. leguminosarum.

\section{MATERIALS AND METHODS}

\section{Bacterial strains, plasmids, and growth conditions.}

Bacterial strains and plasmids are listed in Table 4. Escherichia coli was grown at $37^{\circ} \mathrm{C}$ in Antibiotic Medium No. 3 (Difco, Detroit, MI). Antibiotics, where needed, were used at concentrations as described by Patschkowski et al. (1996). Rhizobium strains were grown in TY medium (Beringer 1974) at $30^{\circ} \mathrm{C}$. When needed, antibiotics were added at concentrations as outlined by Patschkowski et al. (1996). Cultivation of Rhizobium strains under aerobic and microaerobic conditions was done as described elsewhere (Patschkowski et al. 1996). Indicator medium for strains expressing $\beta$-galactosidase activity was supplemented with $40 \mathrm{~g}$ of 5-bromo-4-chloro-3indolyl- $\beta$-D-galactoside (X-gal) per $\mathrm{ml}$ (final concentration). GUS activity was detected on agar medium containing 5bromo-4-chloro-3-indolyl- $\beta$-D-glucuronide (X-Gluc) at a final concentration of $40 \mathrm{~g} / \mathrm{ml}$.

\section{Genetic methods.}

The protocols for mating experiments and mobilization of plasmids between E. coli and Rhizobium strains were as described previously (Simon 1984). Strain LRS393401, cured of both plasmids pRleVF39c and pRleVF39d, was constructed by labeling the plasmids of LRS39401 with Tn5B12S (Hynes et al. 1989) and isolating an insert in pRleVF39c, and subsequently curing the plasmid with $s a c B$ selection, as described by Hynes et al. (1989).

\section{Standard DNA techniques.}

Isolation of total and plasmid DNA was performed as described previously (Priefer 1984; Priefer et al. 1984). Plasmid DNA and DNA fragments were purified with a Qiagen Plasmid Kit (Qiagen, Hilden, Germany) or a Prep-a-Gene Kit (BioRad, Hercules, CA) containing a glass powder suspension according to the manufacturer's instructions. Restriction enzyme digestion, alkaline phosphatase treatment, agarose gel electrophoresis, DNA cloning, and transformations were carried out according to Sambrook et al. (1989). Eckhardt gel analysis was done as outlined by Hynes and McGregor (1990). Southern blotting and hybridization experiments were done by alkaline blotting with Zeta Probe membranes (Bio$\mathrm{Rad}$ ) and digoxygenin-labeled probes (Boehringer Mannheim, Laval, Canada), following the protocols specified by the manufacturers.

\section{Cloning of the R. leguminosarum VF39 fixN homologous regions.}

The clone pLZC6 carrying the $R$. leguminosarum bv. viciae fixN copy from plasmid pRleVF39d was obtained by purifying DNA from plasmids pRleVF39c and pRleVF39d from Eckhardt gels run as described by Hynes and McGregor (1990) by a freeze/squeeze technique, digesting this DNA with EcoRI, and ligating it into dephosphorylated EcoRI-cut pBluescriptIIKS. Clones containing a fixN homologous region were identified by isolating plasmid DNA from transformants, digesting the DNA with EcoRI, and Southern hybridization with the $R$. meliloti fixN', present on plasmid pLZC4, as a probe. pLZC4 carries a 1.7-kb PstI fragment from pTH2 (Renalier et al. 1987) that includes the $\mathrm{N}$ terminal part of the fixN operon (Batut et al. 1989; David et al. 1988). To clone the second fixN copy, a cosmid library of VF39 total DNA in pRK7813 (Jones and Gutterson 1987) was prepared by the procedure outlined by Hynes et al. (1986) with the following modifications: DNA was partially digested with BamHI, and vector DNA was dephosphorylated with a column containing immobilized alkaline phosphatase (purchased from BioCan Scientific, Toronto). Colony hybridization experiments with the fixN region present on plasmid pLZC6 as a probe led to the identification of cosmid clones pLBS3 and pLBS4 carrying the second $R$. leguminosarum VF39 fixN homologous region.

\section{Sequence analysis.}

An 11-kb EcoRI fragment hybridizing to the fixN probe (pLZC6) was subcloned from cosmid pLBS3 into pBluesript-IIKS, resulting in plasmid pFG92. The fixN homologous region could be delimited to a 2.6-kb HindIII/BamHI subfragment of plasmid pFG92. This subfragment was cloned into pBluescript-IIKS, resulting in plasmid pTP94, and subjected to nested deletion formation with a Nested Deletion Kit (Pharmacia, Uppsala, Sweden). Sequencing of the resulting subclones on both strands was done on an A.L.F. DNA Sequencer (Pharmacia) following the instructions of an AutoRead sequencing kit (Pharmacia). In addition, a 3-kb XhoI fragment overlapping the 2.6-kb Hin$\mathrm{dIII} /$ Bam HI fragment by $147 \mathrm{bp}$ was used for sequencing the whole fixN operon. Sequencing of the 3-kb XhoI fragment (present on plasmid pTP93) was achieved as outlined above. The fixN homologous region present on plasmid pLZC6 could be delimited to a 2-kb XhoI fragment by hybridization analysis. This $\mathrm{XhoI}$ fragment was cloned into the sequencing vector pSVB28, resulting in plasmid pSWS1, and subjected to nested deletion formation. Sequencing of the fragment was done as described above. Sequence analysis and determination of the coding probability was done with the computer programs of Staden (1986). The deduced amino acid sequences were compared with the protein data base NCBI Blast E-Mail Server (Altschul et al. 1990; Gish and States 1993). Hydrophobicity analyses were done with the Profilegraph program. 
Construction of $R$. leguminosarum VF39 fixN mutants.

Mutation of the fixNd copy originating from plasmid pRleVF39d was achieved by cloning the 2-kb XhoI fragment carrying fixNd into the SalI site of pJQ200KS and then replacing a fixNd internal $0.575-\mathrm{kb}$ Sall fragment with a spectinomycin (Sp) resistance gene cassette (the $\Omega$ interposon described by Prentki and Krisch [1984] and Fellay et al. [1987]). The resulting plasmid (pJQ245) was used for homogenotization of the fixNd mutation into the plasmid pRleVF39d (as described by Quandt and Hynes [1993]), giving strain VF39-JQ11. Construction of fixNc mutants was carried out in the same fashion by inserting a $\Omega$ Sp cassette and a $\Omega \mathrm{Nm}$ cassette in place of the SalI fragment in pJQ291, to give pJQ292Sp and pJQ292, respectively. A further mutant was created by replacing a large (ca. $4.8 \mathrm{~kb}$ ) Sall fragment that takes in most of the fixN operon and the 5' part of fix $G$ with a $\Omega \mathrm{Nm}$ cassette to give pJQ302 (Quandt and Hynes 1993). Double mutants were created by introducing this latter mutation into strain VF39-JQ11 to give VF39-JQ321. A second double mutant, with fixGc unaffected, was created by recombining pJQ292 into strain VF39-JQ11 to give VF39-JQ1011. All of these mutant strains were verified by the presence of the correct antibiotic resistance markers as well as by Southern hybridization.

\section{Construction of a R. leguminosarum VF39 fixNc-gusA fusion.}

A 522-bp $B c l$ I fragment from plasmid pTP94, containing the $3^{\prime}$ part of fixK and the $5^{\prime}$ end of fixNc, was cloned into the BamHI site of pUC18. A XbaI/PstI gusA cassette originating from plasmid pTP86 was joined to the $5^{\prime}$ part of fixNc, thus creating a fixNc-gusA transcriptional fusion. An EcoRI fragment carrying the fixNc-gusA fusion was subsequently cloned into the mobilizable plasmid pSUP202, resulting in plasmid pTP111.

\section{Construction of a R. leguminosarum VF39 fixNd-gusA fusion.}

A 1,155-bp HindIII/BclI fragment carrying the $5^{\prime}$ end of fixNd (see Figure 2) was cloned into the mobilizable plasmid pK18-mob $\left(\mathrm{Km}^{\mathrm{r}}\right)$. An SmaI/EcoRI gusA cassette originating from plasmid pBI221.1 was ligated to the $5^{\prime}$ part of the fixNd gene, thus creating a fixNd-gusA transcriptional fusion. The resulting plasmid was designated pMK5.

\section{Enzyme tests.}

GUS activity was measured with the substrate p-nitrophenyl- $\beta$-D-glucuronide, as described by Jefferson (1987). GUS units were calculated according to the Miller method as described by Sambrook et al. (1989).

\section{GUS-specific staining of nodule sections.}

Nodules were excised from the roots of $V$. hirsuta plants

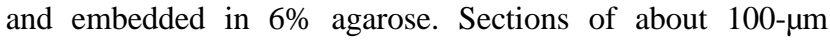
thickness were cut with a manual microtome. Nodule sections were stained for $30 \mathrm{~min}$ in GUS-staining buffer containing 2 $\mathrm{mM}$ potassium-ferricyanide, $2 \mathrm{mM}$ potassium-ferrocyanide, and $2 \mathrm{mM} \mathrm{X}$-Gluc. Stained sections were rinsed in water and transferred onto slides. Sections were photographed with an Olympus OM-4 camera mounted onto an Olympus BX50 microscope.

\section{Plant tests.}

Nodulation and nitrogen fixation tests with P. sativum and $V$. hirsuta as host plants were performed as described by Hynes et al. (1988), with both dry weights and total nitrogen concentrations being measured. As a confirmatory test, acetylene reduction assays for determination of the presence nitrogenase activity were carried out as described by Priefer (1989).

\section{ACKNOWLEDGEMENTS}

We are indebted to Neil Mattatal for technical assistance, and to Pierre Boistard for providing us with $R$. meliloti clones from the fix region. The financial support of an NSERC research grant and a National Biotechnology strategy fund grant to M.F.H., and grants from the Deutsche Forschungsgemeinschaft ( $\operatorname{Pr} 279 / 3-1)$ and the European Community (BIOT-CT90-0166 and CHRX-CT94-0699) to U.B.P., are gratefully acknowledged.

\section{LITERATURE CITED}

Altschul, S. F., Gish, W., Miller, W., Myers, E. W., and Lipman D. J. 1990. Basic local alignment search tool. J. Mol. Biol. 215:403-10.

Anthamatten, D., Scherb, B., and Hennecke, H. 1992. Characterization of a fixLJ-regulated Bradyrhizobium japonicum gene sharing similarity with the Escherichia coli fnr and Rhizobium meliloti fixK genes. J. Bacteriol. 174:2111-2120.

Appleby, C. A. 1984. Leghemoglobin and Rhizobium respiration. Annu. Rev. Plant Physiol. 35:443-478.

Arnold, W., and Pühler, A. 1988. A family of high-copy number plasmid vectors with end-label sites for rapid nucleotide sequencing. Gene 70: 171-179.

Batut, J., Daveran-Mingot, M. L., David, M., Jacobs, J., Garnerone, A. M., and Kahn, D. 1989. fixK, a gene homologous with fnr and crp from Escherichia coli, regulates nitrogen fixation genes both positively and negatively in Rhizobium meliloti. EMBO J. 8:1279-1286.

Beringer, J. E. 1974. R factor transfer in Rhizobium leguminosarum. J. Gen. Microbiol. 84:188-198.

Bullock, J. C., Fernandez, J. M., and Short, J. M. 1987. XL1Blue: A high efficiency plasmid transforming recA Escherichia coli strain with $\beta$-galactosidase selection. BioTechniques 5:376-379.

Colonna-Romano, S., Arnold, W., Schlüter, A., Boistard, P., Pühler, A., and Priefer, U. B. 1990. An Fnr-like protein encoded in Rhizobium leguminosarum biovar viciae shows structural and functional homology to Rhizobium meliloti fixK. Mol. Gen. Genet. 223:138-147.

David, M., Daveran, M. L., Batut, J., Dédieu, A., Domergue, O., Ghai, J., Hertig, C., Boistard, P., and Kahn, D. 1988. Cascade regulation of nif gene expression in Rhizobium meliloti. Cell 54:671-683.

David, M., Domergue O., Pognonec, P., and Kahn, D. 1987. Transcription patterns of Rhizobium meliloti symbiotic plasmid pSym: Identification of nifA-independent fix genes. J. Bacteriol. 169:2239-2244.

de Gier, J.-W. L., Schepper, M., Reijnders, W. N. M., van Dyck, S. J., Slotboom, D. J., Warne, A., Saraste, M., Krab, K., Finel, M., Stouthamer, A. H., van Spanning, R. J. M., and van der Oost, J. 1996. Structural and functional analysis of aa3-type and cbb3-type cytochrome c oxidases of Paracoccus denitrificans reveals significant differences in proton pump design. Mol. Microbiol. 20:1247-1260.

D'hooge I., Michiels J., Vlassak K., Verreth C., Waelkens F., and Vanderleyden J. 1995. Structural and functional analysis of the fixLJ genes of Rhizobium leguminosarum biovar phaseoli CNPAF512. Mol. Gen. Genet. 249:117-126.

Fellay, R., Frey, J., and Krisch, H. 1987. Interposon mutagenesis of soil and water bacteria: A family of DNA fragments designed for in vitro insertional mutagenesis of Gram-negative bacteria. Gene 52:147-154.

Fischer, H. M. 1994. Genetic regulation of nitrogen fixation in rhizobia. Microbiol. Rev. 58:352-386.

Fisher R. F., and Long, S. R. 1992. Rhizobium-plant signal exchange. Nature 357:655-660.

Gish, W., and States, D. W. 1993. Identification of protein coding regions by database similarity search. Nature Genet. 3:266-272.

Hernando, Y., Palacios, J. M., Imperial, J., and Ruiz Argueso, T. 1995. 
The hypBFCDE operon from Rhizobium leguminosarum biovar viciae is expressed from an Fnr-type promoter that escapes mutagenesis of the fnrN gene. J. Bacteriol. 177:5661-5669.

Hunt, S., and Layzell, D. B. 1993. Gas exchange of legume nodules and the regulation of nitrogenase activity. Annu. Rev. Plant Physiol. Plant Mol. Biol. 44:483-511.

Hynes, M. F., Brucksch, K., and Priefer, U. B. 1988. Melanin production encoded by a cryptic plasmid in a Rhizobium leguminosarum strain. Arch. Microbiol. 150:326-332.

Hynes, M. F., and McGregor, N. F. 1990. Two plasmids other than the nodulation plasmid are necessary for formation of nitrogen-fixing nodules by Rhizobium leguminosarum. Mol. Microbiol. 4:567-571.

Hynes, M. F., Quandt, J., O'Connell, M. P., and Pühler, A. 1989. Direct selection for curing and deletion of Rhizobium plasmids using transposons carrying the Bacillus subtilis sacB gene. Gene 78:111-120.

Hynes, M. F., Simon, R., Müller, P., Niehaus, K., Labes, M., and Pühler, A. 1986. The two megaplasmids of Rhizobium meliloti are involved in the effective nodulation of alfalfa. Mol. Gen. Genet. 202:356-362.

Jefferson, R. A. 1987. Assaying chimeric genes in plants: The GUS fusion system. Plant Mol. Biol. Rep. 5:387-405.

Jones, J. D. G., and Gutterson, N. 1987. An efficient mobilizable cosmid vector, pRK7813, and its use in a rapid method for marker exchange in Pseudomonas fluorescens strain HV37a. Gene 61:299-306.

Jordan, D. C. 1984. Rhizobium. Pages 235-242 in: Bergey's Manual of Systematic Bacteriology. Vol. 1. N. R. Krieg and J. G. Holt, eds. Williams and Wilkins, Baltimore.

Kahn, D., Batut, J., Daveran, M. L., and Fourment, J. 1993. Structure and regulation of the fixNOQP operon of Rhizobium meliloti. Page 474 in: New Horizons in Nitrogen Fixation. R. Palacios, J. Mora, and W. E. Newton, eds. Kluwer Academic Pub., Dordrecht, The Netherlands.

Kahn, D., David, M., Domergue, O., Daveran, M.-L., Ghai, J., Hirsch, P. R., and Batut, J. 1989. Rhizobium meliloti fixGHI sequence predicts involvement of a specific cation pump in symbiotic nitrogen fixation. J. Bacteriol. 171:929-939.

Kaminski, P. A., Mandon, K., Arigoni, F., Desnoues, N., and Elmerich, C. 1991. Regulation of nitrogen fixation in Azorhizobium caulinodans: Identification of a fixK-like gene, a positive regulator of nifA. Mol. Microbiol. 5:1983-1991.

Long, S. R., and Staskawicz, B. J. 1993. Prokaryotic plant parasites. Cell 72: 921-935.

Mandon, K., Kaminski P. A., Mougel, C., Desnoues, N., Dreyfus, B., and Elmerich, C. 1993. Role of the fixGHI region of Azorhizobium caulinodans in free-living and symbiotic nitrogen fixation. FEMS Microbiol. Lett. 114:185-190.

Mandon, K., Kaminski, P. A., and Elmerich, C. 1994. Functional analysis of the fixNOQP region of Azorhizobium caulinodans. J. Bacteriol. 176:2560-2568.

Martinez-Romero, E., and Caballero-Mellado, J. 1996. Rhizobium phylogenies and bacterial genetic diversity. CRC Crit. Rev. Plant Sci. 15:113-140.

Patschkowski, T., Schlüter, A., and Priefer, U. B. 1996. Rhizobium leguminosarum bv. viciae contains a second fnr/fixK-like gene and an unusual fixL homologue. Mol. Microbiol. 21:267-280.

Pearson, W. R. 1990. Rapid and sensitive sequence comparison with FASTP and FASTA. Methods Enzymol. 183:63-98.

Preisig, O., Anthamatten, D., and Hennecke, H. 1993. Genes for a microaerobically induced oxidase complex in Bradyrhizobium japonicum are essential for a nitrogen-fixing endosymbiosis. Proc. Natl. Acad. Sci. USA 90:3309-3313.

Preisig, O., Zufferey, R., and Hennecke, H. 1996a. The Bradyrhizobium japonicum fixGHIS genes are required for the formation of the highaffinity cbb3-type cytochrome oxidase. Arch. Microbiol. 165:297305.

Preisig, O., Zufferey, R., Thöny-Meyer, L., Appleby, C. A., and Hennecke, H. 1996b. A high-affinity cbb3-type cytochrome oxidase terminates the symbiosis-specific respiratory chain of Bradyrhizobium japonicum. J. Bacteriol. 178:1532-1538.

Prentki, P., and Krisch, H. M. 1984. In vitro insertional mutagenesis with a selectable DNA fragment. Gene 29:303-313.

Priefer, U. B. 1984. Isolation of plasmid DNA. Pages 14-24 in: Advanced Molecular Genetics. A. Pühler and K. N. Timmis, eds. Springer Verlag, Berlin.

Priefer, U. B. 1989. Genes involved in lipopolysaccharide production and symbiosis are clustered on the chromosome of Rhizobium leguminosarum biovar viciae VF39. J. Bacteriol. 171:6161-6168.

Priefer, U. B., Simon, R., and Pühler, A. 1984. Cloning with cosmids. Pages 190-201 in: Advanced Molecular Genetics. A. Pühler and K. N. Timmis, eds. Springer Verlag, Berlin.

Quandt, J., and Hynes, M. F. 1993. Versatile suicide vectors which allow direct selection for gene replacement in gram-negative bacteria. Gene 127:15-21

Renalier, M.-H., Batut, J., Ghai, J., Terzaghi, B., Ghérardi, M., David, M., Garnerone, A.-M., Vasse, J., Truchet, G., Huguet, T., and Boistard, P. 1987. A new symbiotic cluster on the pSym megaplasmid of Rhizobium meliloti 2011 carries a functional fix gene repeat and a nod locus. J. Bacteriol. 169:2231-2238.

Sambrook, J., Fritsch, E. F., and Maniatis, T. A. 1989. Molecular Cloning: A Laboratory Manual. Cold Spring Harbor Laboratory, Cold Spring Harbor, NY

Schäfer, A., Tauch, A., Jäger, W., Kalinowski, J., Thierbach, G., and Pühler, A. 1994. Small mobilisable multi-purpose cloning vectors derived from the Escherichia coli plasmids pK18 and pK19: Selection of defined deletions in the chromosome of Corynebacterium glutamicum. Gene 145:69-73.

Schlüter, A., Patschkowski, T., Unden, G. and Priefer, U. B. 1992. The Rhizobium leguminosarum FnrN protein is functionally similar to Escherichia coli Fnr and promotes heterologous oxygen-dependent activation of transcription. Mol. Microbiol. 6:3395-3404.

Schlüter, A., Rüberg, S., Krämer, M., Weidner, S., and Priefer, U. B. 1995. A homolog of the Rhizobium meliloti nitrogen fixation gene fixN is involved in the production of a microaerobically induced oxidase activity in the phytopathogenic bacterium Agrobacterium tumefaciens. Mol. Gen. Genet. 247:206-215.

Simon, R. 1984. High frequency mobilization of gram negative bacterial replicons using the in vitro constructed Tn5-Mob transposon. Mol. Gen. Genet. 196:413-420.

Simon, R., Priefer, U. B., and Puhler, A. 1983. A broad host range mobilization system for in vivo genetic engineering: Transposon mutagenesis in Gram negative bacteria. Bio/Technology. 1:784-791.

Staden, R. 1986. The current status and portability of our sequence handling software. Nucleic Acids. Res. 14:217-231.

Thöny-Meyer, L., Beck, C., Preisig, O., and Hennecke, H. 1994. The ccoNOQP gene cluster codes for a cb-type cytochrome oxidase that functions in aerobic respiration of Rhodobacter capsulatus. Mol. Microbiol. 14:705-716.

Tripathi, A. K. 1993. Existence of fixJ- and fixK-like genes in Azospirillum brasilense. Indian J. Exp. Biol. 31:559-561.

Van Rhijn, P., and Vanderleyden, J. 1995. The Rhizobium-plant symbiosis. Microbiol. Rev. 59:124-142.

Vargas, C., Wu, G., Delgado, M.-J., Poole, R. K., and Downie, J. A. 1996. Identification of symbiosis-specific c-type cytochromes and a putative oxidase in bacteroids of Rhizobium leguminosarum biovar viciae. Microbiology 142:41-46.

Vieira, J., and Messing, J. 1982. The pUC plasmids, an M13mp7derived system for insertion mutagenesis and sequencing with synthetic universal primers. Gene 19:259-268.

Yannisch-Perron, C., Vieira, J., and Messing, J. 1985. Improved M13 phage cloning vectors and host strains: Nucleotide sequences of the M13mp18 and pUC19 vectors. Gene 33:103-119.

Zufferey, R., Preisig, O., Hennecke, H., and Thöny-Meyer, L. 1996. Assembly and function of the cytochrome cbb3 oxidase subunits in Bradyrhizobium japonicum. J. Biol. Chem. 271:9114-9119. 